\title{
The effect of time of release on microhabitat use by the white-footed mouse
}

\author{
Michael A. MENZEL, Timothy C. CARTER, \\ Loren R. JABLONOWSKI and Joshua LAERM
}

\begin{abstract}
Menzel M. A., Carter T. C., Jablonowski L. R. and Laerm J. 2000. The effect of time of
\end{abstract} release on microhabitat use by the white-footed mouse. Acta Theriologica 45: 167-173.

Fluorescent paint powders have frequently been used to determine the spatial activity patterns and microhabitat use of small mammals. The time of day that powdered animals were released differs among studies and data used in many studies were collected on the trails of powdered animals released in the morning outside the normal period of activity of many species of small mammals. We tested for differences in the characteristics of fluorescent powder trails of white-footed mice Peromyscus leucopus (Rafinesque, 1818) released using three protocols: night capture-night release, morning capture-morning release, and morning capture-delayed night-release. The night release and morning release protocols were established to replicate the extremes found in the literature. We added the third protocol to evaluate how capturing mice in the morning, holding them in captivity, and releasing them at night affected their use of microhabitat. There were no significant differences in the use of microhabitat between the night release and delayed night-release treatments. However, a significantly greater proportion of the trails of mice released in the morning were in areas of thick cover and under logs than the trails of mice released at night. Because mice released during the day used microhabitat differently than mice released at night, we caution against the interpretation of data on use of habitat collected using the fluorescent powder trails of animals released outside their normal period of activity.

Division of Forestry, P.O. Box 6125, West Virginia University, Morgantown, WV 26506, USA, e-mail: mamenzel1@juno.com (MAM); Department of Zoology, Southern Illinois University, Carbondale, IL 62901, USA, (TCC); D. B. Warnell School of Forest Resources, University of Georgia, Athens, GA 30602, USA (LRJ); Museum of Natural History, University of Georgia, Athens, GA 30602, USA (JL)

Key words: Peromyscus leucopus, fluorescent powder tracking, microhabitat use

\section{Introduction}

Routes taken by animals during daily activities are important aspects of animal behavior. However, quantifying patterns of movement is often difficult. Many small mammals are nocturnal and secretive; this makes the study of movement patterns and use of microhabitat difficult. Many studies employ live-trapping techniques to determine use of microhabitat by small mammals (Kaufman et al. 1983, McShea and Franq 1984, Seagle 1985). Since bait used in traps may affect animal movements, point data on microhabitat use obtained from trapping may be biased (Sheppe 1967). Radio telemetry can provide information about movements and 
Table 1. Studies of rodent activity patterns and habitat use by fluorescent powder tracking showing range of times traps have been checked and animals released.

\begin{tabular}{lll}
\hline Study & Time traps were checked & Time animals were released \\
\hline Kaufman 1989 & $1-3 \mathrm{~h}$ after sunset & that night \\
Jike et al. 1988 & morning & that morning \\
Mullican 1988 & night & that night \\
Goodyear 1989 & not indicated & approximately $19.00 \mathrm{~h}$ \\
Barnum et al. 1992 & $23.30-04.00 \mathrm{~h}$ & at time of capture \\
McShea and Gilles 1992 & $22.00 \mathrm{~h}$ & at time of capture \\
Etheredge et al. 1989 & $05.00-09.00 \mathrm{~h}$ & at time of capture \\
Mullican and Baccus 1990 & $17.00-09.00 \mathrm{~h}$ & $17.00-20.00 \mathrm{~h}$ that evening \\
\hline
\end{tabular}

home ranges, but it is limited by range of transmitter, expense of equipment, error associated with triangulation, and the potential for the researcher's presence to alter the animals' activity patterns and movements. In addition, although radio telemetry provides point data on use of habitat, detailed information on how the animal travels between points is difficult to obtain.

Fluorescent-powder tracking is a popular technique used to study various aspects of the behavior of small, nocturnal mammals. The low costs and high accuracy of powder tracking has caused this technique to become favored by many researchers. Since it was first proposed by Lemen and Freeman (1985), fluorescent pigments have been used to examine movements (Jike et al. 1988, Mullican 1988, Teferi and Herman 1995), intraspecific social interactions (Kaufman 1989, Millar and Erickson 1992), foraging behavior (McShea and Gilles 1992), and use of habitat (Graves et al. 1988, Goodyear 1989, Etheredge et al. 1989, Mullican and Baccus 1990, Barnum et al. 1992, McMillan and Kaufman 1995) of a number of species of small mammals. The basic technique involves live-trapping animals, immersing them in fluorescent powder, releasing them at the point of capture, then following and marking the fluorescent trails (Lemen and Freeman 1985). Lemen and Freeman (1985) set traps at sunset and checked them about three hours later, at which time they powdered and released the animals. However in other studies, capture and release times ranged throughout the night (Table 1). We hypothesized that differences in time-of-release might influence animal behavior or activity patterns, particularly their use of cover. We designed an experiment to test the affect time-of-release would have on use of microhabitat features by white-footed mice Peromyscus leucopus (Rafinesque, 1818).

\section{Study site}

We conducted our study in Athens-Clark County, Georgia ( $33^{\circ} 53^{\prime} \mathrm{N}, 83^{\circ} 23^{\prime} \mathrm{W}$, Elev. $\left.250 \mathrm{~m}\right)$, during May 1997. The study site was a 25 ha one-year-old clear-cut dominated by blackberry (Rubus spp.), sweetgum (Liquidamber styraciflua) and various grasses (Poacea). Coarse woody debris (CWD) in the 
form of logging slash was common throughout the site. The logging slash primarily consisted of the tops and limbs $(<9 \mathrm{~cm}$ diam $)$ of loblolly pines.

\section{Material and methods}

We captured animals using 175 Sherman live traps $(6.5 \times 5.5 \times 16.5 \mathrm{~cm})$ baited with rolled oats and set for five nights. Traps were set next to logging slash and were checked at night $(23.00 \mathrm{~h})$ and in the morning $(07.00 \mathrm{~h})$. We established three time-of-release protocols: night capture-night release, morning capture-morning release, and morning capture-delayed night-release. The night capture-night release and morning capture-morning release protocols were established to replicate the extremes found in the literature (Table 1). We added the third protocol to evaluate the effect of morning capture-night release on the movements of mice. We compared use of habitat by mice among the three different time-of-release protocols. Over five nights of trapping, we dusted 35 mice with fluorescent powder (Radiant Color, Richmond, CA 94804) following the method of Lemen and Freeman (1985). Ten mice ( 5 males and 5 females) captured at night $(23.00 \mathrm{~h}$ ) were released immediately after capture (night release). Thirteen mice ( 5 males and 8 females) captured during the morning $(07.00 \mathrm{~h})$ were placed in cages (with sunflower seeds and water) in a secure, shaded structure for $36 \mathrm{~h}$ and released at night $(23.00 \mathrm{~h}$, delayed night-release). Twelve mice (6 males and 6 females) captured in the morning $(07.00$ h) were powdered and immediately released (morning release). Only adult, non-lactating mice were tracked. Mice were trapped and released only during clear (ie non-overcast) weather. The average daily and nightly temperatures during the study were 17.2 and $30.0^{\circ} \mathrm{C}$, respectively. All mice were powdered and released at the point of capture. The treatment applied to each mouse was ascribed at random with respect to location of capture in the clearcut. We examined fluorescent powder trails the night following release using ultraviolet light and marked them with fluorescent flags. We placed flags every $1-\mathrm{m}$ along the trail and at each point where the trail turned. We followed all trails until the fluorescent powder was no longer visible.

We characterized microhabitat features along each segment of each trail. On each trail we determined the presence of CWD, absence of CWD (open), whether the trail passed on, beside, or under the CWD, and we visually estimated density of ground cover (leaf litter, herbaceous cover, or woody cover up to 1-m in height). We subjectively assigned the density of cover into one of three cover classes based on the vulnerability of the mice to predators. We assigned a value of one to sections of trails with little protection, value of two to sections of trails with moderate protection, and a value of three to sections of trails that offered a high level of protection. Using a Daubemire square, we quantitatively measured the density of vegetation in a random sample of each of the three cover classes to ground-truth our classification system (Mueller-Dombois and Ellenberg 1974). The percent of the trail covered

Table 2. Descriptions of the nine classes used to describe the location of sections of fluorescent powder trails left by white-footed mice.

Trail class

Description

Open 1

Open 2

Open 3

On $\log 1$

On $\log 2$

On $\log 3$

Beside log

Under log

In tree away from course woody debris (CWD), little vegetative cover above the trail (0-33\%) away from CWD, moderate vegetative cover above the trail (34-66\%)

away from CWD, thick vegetative cover above the trail (67-100\%)

on top of a log, little vegetative cover above the trail $(0-33 \%)$ on top of a log, moderate vegetative cover above the trail (34-66\%) on top of a log, thick vegetative cover above the trail (67-100\%) beside a log that is partially buried (included in cover class 3 ) under a log that is not buried (included in cover class 3 ) on CWD (live or snag) that is standing vertically (included in cover class 1) 
by vegetation in the three cover classes $(12.5,50.6$, and $89.0 \%$ for class 1,2 , and 3 respectively) differed significantly $(F=82.87, \mathrm{df}=2, p=0.0001)$. Sections of trails beside or under CWD were assigned to cover class three. Sections of trails on trees were assigned to cover class one. Based on a combination of these characterizations, we defined nine trail classes: open 1 , open 2 , open 3 , on-log 1 , on- $\log 2$, on-log 3 , beside log, under log, and in tree (see Table 2 for a description of the nine trail classes).

In addition to comparing use of microhabitat by white-footed mice released during the day with those released at night, we also compared use of microhabitat by mice released using each protocol with available habitat. We calculated available habitat by sampling eight randomly established $20-\mathrm{m}$ straight-line transects in the clearcut using the same techniques and habitat variables described above.

We compared the proportion of trails in each trail class, proportions associated with CWD irrespective of cover thickness, and proportions of trails associated with each cover thickness irrespective of CWD among the three release protocols and random transects using analysis of variance (ANOVA) and Duncan's multiple means comparison (SAS/STAT 1988). Since proportional data are not normally distributed, we transformed all proportional values using an arcsin square root transformation prior to all analyses. All means reported are untransformed.

\section{Results}

We tracked 35 white-footed mice: 16 males and 19 females. The average length of trails did not differ between the release protocols $(F=0.50, \mathrm{df}=2, p=0.6857$, Table 3). The trails of mice captured in the morning, held throughout the day, and released the following night (delayed night-released) did not differ from the trails of mice captured at night and released immediately (night-released, Tables 3 and 4). The trails of mice released after dark (delayed night-released or night-released) differed from trails of mice released in the morning. A greater proportion of the trails of mice released after dark were on logs with little cover than trails of mice released in the morning ( $F=5.73$, df $=3, p=0.0029$, Table 4$)$. A greater proportion of the trails of mice released in the morning were under logs than the trails of mice released at night $(F=3.13, \mathrm{df}=3, p=0.0386$, Table 4). Regardless of

Table 3. A comparison (ANOVA) of mean proportion of the length of fluorescent powder trails in areas of little, moderate, and heavy vegetative cover (cover classes 1,2 , and 3 respectively), length of trails away from course woody debris (CWD), length of trails on, under, or beside CWD, and total trail length among the trails of white-footed mice released in the morning immediately following capture (moming release), mice released at night immediately following capture (night release), mice captured ir the morning, held, and released at night (delayed release), and random transects. Means within a row followed by the same letter are not significantly different $(p>0.05)$.

\begin{tabular}{|c|c|c|c|c|c|c|c|c|}
\hline \multirow{2}{*}{$\begin{array}{l}\text { Trail } \\
\text { characteristics }\end{array}$} & \multicolumn{2}{|c|}{ Morning release } & \multicolumn{2}{|c|}{ Night release } & \multicolumn{2}{|c|}{ Delayed release } & \multicolumn{2}{|c|}{ Random transect } \\
\hline & Mean & SE & Mean & SE & Mean & $\mathrm{SE}$ & Mean & $\mathrm{SE}$ \\
\hline Cover $1(0-30 \%)$ & $0.22 \mathrm{~B}$ & 0.05 & $0.43 \mathrm{AB}$ & 0.07 & $0.50 \mathrm{~A}$ & 0.07 & $0.37 \mathrm{AB}$ & 007 \\
\hline Cover $2(31-65 \%)$ & $0.18 \mathrm{~B}$ & 0.04 & $0.15 \mathrm{~B}$ & 0.02 & $0.25 \mathrm{~B}$ & 0.06 & $0.39 \mathrm{~A}$ & 002 \\
\hline Cover $3(66-100 \%)$ & $0.60 \mathrm{~A}$ & 0.07 & $0.42 \mathrm{AB}$ & 0.08 & $0.25 \mathrm{~B}$ & 0.04 & $0.25 \mathrm{~B}$ & 008 \\
\hline Away from CWD & $0.53 \mathrm{~B}$ & 0.07 & $0.45 \mathrm{~B}$ & 0.05 & $0.57 \mathrm{~B}$ & 0.06 & $0.89 \mathrm{~A}$ & 005 \\
\hline Total CWD & $0.47 \mathrm{~A}$ & 0.07 & $0.55 \mathrm{~A}$ & 0.05 & $0.43 \mathrm{~A}$ & 0.05 & $0.11 \mathrm{~B}$ & 005 \\
\hline Trail length $(\mathrm{cm})$ & 1857.9 & 441.3 & 1810.0 & 333.7 & 2224.3 & 670.8 & 2000.0 & 00 \\
\hline
\end{tabular}


Table 4. A comparison (ANOVA) of mean proportion of nine trail characteristics among fluorescent powder trails of white-footed mice released in the morning immediately following capture (morning release), mice released at night immediately following capture (night release), mice captured in the morning, held, and released at night (delayed release), and random transects. Means within a row followed by the same letter are not significantly different $(p>0.05)$.

\begin{tabular}{|c|c|c|c|c|c|c|c|c|}
\hline \multirow{2}{*}{$\begin{array}{l}\text { Trail } \\
\text { characteristics }\end{array}$} & \multicolumn{2}{|c|}{ Morning release } & \multicolumn{2}{|c|}{ Night release } & \multicolumn{2}{|c|}{ Delayed release } & \multicolumn{2}{|c|}{ Random transect } \\
\hline & Mean & SE & Mean & SE & Mean & $\mathrm{SE}$ & Mean & $\mathrm{SE}$ \\
\hline Open $1(0-30 \%)$ & $0.12 \mathrm{~B}$ & 0.03 & $0.16 \mathrm{~B}$ & 0.05 & $0.23 \mathrm{AB}$ & 0.07 & $0.34 \mathrm{~A}$ & 0.07 \\
\hline Open $2(31-65 \%)$ & $0.15 \mathrm{~B}$ & 0.04 & $0.10 \mathrm{~B}$ & 0.02 & $0.19 \mathrm{~B}$ & 0.06 & $0.39 \mathrm{~A}$ & 0.05 \\
\hline Open $3(66-100 \%)$ & 0.26 & 0.08 & 0.19 & 0.05 & 0.14 & 0.05 & 0.16 & 0.03 \\
\hline On $\log 1(0-30 \%)$ & $0.09 \mathrm{~B}$ & 0.05 & $0.26 \mathrm{~A}$ & 0.06 & $0.27 \mathrm{~A}$ & 0.05 & $0.03 \mathrm{~B}$ & 0.00 \\
\hline On $\log 2(31-65 \%)$ & $0.03 \mathrm{AB}$ & 0.02 & $0.05 \mathrm{~A}$ & 0.02 & $0.03 \mathrm{~A}$ & 0.01 & $0.00 \mathrm{~B}$ & 0.00 \\
\hline On log $3(66-100 \%)$ & 0.04 & 0.02 & 0.03 & 0.02 & 0.01 & 0.01 & 0.00 & 0.00 \\
\hline Beside log & 0.11 & 0.05 & 0.04 & 0.02 & 0.04 & 0.02 & 0.03 & 0.02 \\
\hline Under log & $0.20 \mathrm{~A}$ & 0.05 & $0.16 \mathrm{AB}$ & 0.06 & $0.05 \mathrm{~B}$ & 0.02 & $0.04 \mathrm{~B}$ & 0.02 \\
\hline In tree & 0.00 & 0.00 & 0.01 & 0.01 & 0.03 & 0.02 & 0.00 & 0.00 \\
\hline
\end{tabular}

whether the trails were near or away from CWD, a greater proportion of the trails of mice release during the day were under thick cover (66-100\%) than trails of mice released after being held $36 \mathrm{~h}(F=7.40, \mathrm{df}=3, p=0.0006$, Table 3$)$. Based on expected values from the random transects, a greater proportion of the trails of mice released in all three treatments were associated with CWD than expected based on the availability of logs in the clearcut $(F=20.92, \mathrm{df}=3, p=0.0001$, Table 3 ). A greater proportion of the trails of mice released at night (both night-release and delayed night-release protocols) were on top of logs in areas with little vegetative cover than expected based on the availability of this type of microhabitat $(F=5.73, \mathrm{df}=3, p=0.0029$, Table 4$)$. A lower proportion of the trails of mice released at night immediately following capture and mice released during the day were in areas with little vegetative cover away from CWD than expected based on the availability of this microhabitat $(F=3.77, \mathrm{df}=3, p=0.0198$, Table 4$)$. A greater proportion of the trails of mice released during the day were under CWD than expected based on the abundance of logs in the clearcut $(F=3.13, \mathrm{df}=3, p=$ 0.0386, Table 4).

\section{Discussion}

Patterns of habitat use collected using fluorescent powder tracking may depend on when animals are powdered and released. White-footed mice use structural landmarks to navigate and their use of logs and other CWD for escape paths following release from live traps has been documented (Kaufman et al. 1983, Drickamer and Stuart 1984). Differences in the use of habitat features among the 
release protocols probably were a reflection of behavioral responses to daytime exposure and predator avoidance. The list of predators that commonly feed on white-footed mice in the southeastern United States include animals with nocturnal (eg barred Strix varia, eastern screech Otus asio, and barn Tyto alba owls), crepuscular (eg red foxes Vulpes vulpes and bobcats Lynx rufus), and diurnal (red-shouldered Buteo lineatus and red-tailed B. jamaicensis hawks) activity patterns. Because use of habitat differed significantly between mice released during the day and mice released at night, we caution against the interpretation of data on habitat use collected using powder tracking outside the animal's normal period of activity. To avoid bias relating to different behavior responses because of time of release, we suggest data be collected at a time appropriate to the typical activity pattern of the species studied. We recognize that although many species of mammals are nocturnal, logistical constraints often prevent researchers from checking their traps at night. Our results suggest that if logistical constraints require nocturnal animals be removed from traps during the morning rather than at night, activity patterns observed through powder tracking will more closely mirror those of night captured-night released animals if individuals are held throughout the day and released the following night rather than released immediately following capture.

Acknowledgments: This project was funded by the University of Georgia Museum of Natural History. We thank B. L. Mitchell, N. Van Der Maath and S. B. Castleberry for field assistance, and T. S. McCay and J. M. Maness for editorial comments.

\section{References}

Barnum S. A., Manville C. J., Tester J. R. and Carmen W. J. 1992. Path selection by Peromyscus leucopus in the presence and absence of vegetative cover. Journal of Mammalogy 73: 797-801.

Drickamer L. C. and Stuart J. 1984. Peromyscus: snow tracking and possible cues used for navigation. American Midland Naturalist 111: 202-204.

Etheredge D. R., Engstrom M. D. and Stone R. C. 1989. Habitat discrimination between sympatric populations of Peromyscus attwateri and Peromyscus pectoralis in west-central Texas. Journal of Mammalogy 70: 300-307.

Goodyear N. C. 1989. Studying fine-scale habitat use in small mammals. The Journal of Wildlife Management 53: 941-946.

Graves S., Maldonado J. and Wolff J. O. 1988. Use of ground and arboreal microhabitats by Peromyscus leucopus and Peromyscus maniculatus. Canadian Journal of Zoology 66: 277-278.

Jike L., Batzli G. O. and Getz L. L. 1988. Home ranges of prairie voles as determined by radiotracking and by powder tracking. Journal of Mammalogy 69: 183-186.

Kaufman D. W., Peterson S. K., Fristik R. and Kaufman G. A. 1983. Effect of microhabitat features on habitat use by Peromyscus leucopus. American Midland Naturalist 110: 177-185.

Kaufman G. A. 1989. Use of fluorescent pigments to study social interactions in a small nocturnal rodent, Peromyscus maniculatus. Journal of Mammalogy 70: 171-174.

Lemen C. A. and Freeman P. F. 1985. Tracking mammals with fluorescent pigments: a new method. Journal of Mammalogy 66: 134-136.

McMillan B. R. and Kaufman D. W. 1995. Travel path characteristics for free-living white-footed mice (Peromyscus leucopus). Canadian Journal of Zoology 73: 1474-1478. 
McShea W. J. and Franq E. N. 1984. Microhabitat selection by Peromyscus leucopus. Journal of Mammalogy 65: 675-678.

McShea W. J. and Gilles A. B. 1992. A comparison of traps and fluorescent powder to describe foraging for mast by Peromyscus leucopus. Journal of Mammalogy 73: 218-222.

Millar J. S. and Erickson E. M. 1992. Group nesting in Peromyscus maniculatus. Journal of Mammalogy 73: 403-407.

Mueller-Dombois D. and Ellenberg H. 1974. Aim and methods of vegetation ecology. John Wiley and Sons, New York: 1-547.

Mullican T. R. 1988. Radio telemetry and fluorescent pigments: a comparison of techniques. The Journal of Wildlife Management 52: 627-631.

Mullican T. R. and Baccus J. T. 1990. Horizontal and vertical movements of the white-ankled mouse, (Peromyscus pectoralis) in central Texas. Journal of Mammalogy 71: 378-381.

SAS/STAT 1988. SAS/STAT users guide, Release 6.03 edition. SAS Institute, Cary, North Carolina.

Seagle S. W. 1985. Patterns of small mammal microhabitat utilization in cedar glade and deciduous forest habitats. Journal of Mammalogy 66: 22-35.

Sheppe W. 1967. The effect of live-trapping on the movements of Peromyscus. American Midland Naturalist 78: 471-480.

Teferi T. and Herman T. B. 1995. Epigeal movement by Sorex cinereus on Bon Portage, Nova Scotia. Journal of Mammalogy 76: 137-140.

Received 20 December 1998, accepted 26 October 1999. 